\title{
Hubungan antara Migrain dan Kafein
}

\section{Matthew A. Kumaat, ${ }^{1}$ Junita M. Pertiwi, ${ }^{2}$ Arthur H. P. Mawuntu ${ }^{2}$}

\author{
${ }^{1}$ Program Studi Pendidikan Dokter Fakultas Kedokteran Universitas Sam Ratulangi, Manado, \\ Indonesia \\ ${ }^{2}$ Bagian/KSM Neurologi Fakultas Kedokteran Universitas Sam Ratulangi/RSUP Prof. dr. R. \\ D. Kandou, Manado, Indonesia \\ Email: 17011101045@student.unsrat.ac.id
}

\begin{abstract}
Migraine is one of the primary headaches that often causes moderate to severe disability. One of the most commonly consumed psychoactive substances associated with migraine is caffeine. This study was aimed to evaluate the relationship between migraine and caffeine thoroughly based on various studies. This was a literature review study using databases of Pubmed/Medline, Cochrane, Wiley Online Library, Science Direct, Google Scholar, and Garuda. The eligibility criteria for this study were observational research articles or clinical trials, written in Indonesian or English, published in the last five years, and their fulltexts could be accessed. The results obtained 10 articles. Almost all of them showed that caffeine could cause migraine whether after caffeine consumption (non-absent group) or no consumption of caffeine (absent group). The association of caffeine with migraine was more significant than with tension headaches. Besides being a trigger factor of migraine, caffeine cpuld also act as a migraine therapy. In conclusion, there is a close association between migraine and caffeine. Migraine tends to be triggered than to be reduced by caffeine.
\end{abstract}

Keywords: caffeine, migraine

\begin{abstract}
Abstrak: Migrain merupakan salah satu jenis nyeri kepala primer yang sering menyebabkan disabilitas sedang dan berat. Salah satu zat psikoaktif yang umum dikonsumsi dan berhubungan dengan migrain yaitu kafein. Penelitian ini bertujuan untuk menelaah hubungan migrain dan kafein lebih mendalam berdasarkan berbagai penelitian. Jenis penelitian ialah literature review menggunakan database dari Pubmed/Medline, Cochrane, Wiley Online Library, Science Direct, Google Scholar, dan Garuda. Kriteria kelayakan artikel penelitian ialah artikel penelitian observasional atau uji klinis, ditulis dalam Bahasa Indonesia atau Inggris, terbit dalam lima tahun terakhir, dan naskah lengkap artikel dapat diakses secara lengkap. Hasil penelitian mendapatkan 10 artikel penelitian. Hampir semua penelitian memperlihatkan bahwa kafein dapat menyebabkan migrain baik setelah kafein dikonsumsi (kelompok nonabsen) maupun saat kafein sudah tidak dikonsumsi (kelompok absen). Hubungan kafein dengan migrain lebih kuat dibandingkan dengan nyeri kepala tipe tegang. Selain menjadi factor pencetus, kafein juga dapat berperan sebagai terapi migrain. Simpulan penelitian ini ialah terdapat hubungan erat antara migrain dan kafein. Migrain cenderung lebih sering dicetuskan oleh kafein dibandingkan diringankan oleh kafein.
\end{abstract}

Kata kunci: kafein, migrain

\section{PENDAHULUAN}

Migrain adalah salah satu jenis nyeri kepala primer yang didefinisikan sebagai nyeri kepala berulang yang sangat bervariasi dalam hal intensitas, kekerapan, dan lama perlangsungan. Serangan nyeri kepala ini sering terjadi pada salah satu sisi kepala, disertai penurunan nafsu makan dan, terkadang mual-muntah. Pada beberapa pasien sering didahului oleh atau berhubungan dengan gangguan rasa, kemampuan bergerak, atau suasana hati; dan nyeri kepala ini sering 
menurun dalam keluarga. ${ }^{1}$ Migrain dibedakan dari nyeri kepala primer yang lain yaitu nyeri kepala tipe tegang dan nyeri kepala autonom trigeminal karena memiliki gambaran klinis berupa nyeri kepala berdenyut, unilateral, dalam intensitas yang berat, dan berlangsung selama 4-72 jam, diperberat oleh aktivitas fisik, serta disertai gejala tambahan seperti fotofobia (sensitivitas terhadap cahaya), fonofobia (sensitivitas terhadap suara), dan juga mual dan muntah. ${ }^{1,2}$ Migrain dialami oleh $18 \%$ perempuan dan 6\% laki-laki di Amerika Serikat sedangkan di Indonesia, prevalensinya belum jelas. ${ }^{3}$ Makanan, perubahan lingkungan, aktivitas fisik, rangsangan sensorik, dan stres merupakan faktor-faktor pencetus utama serangan nyeri kepala pada migrain. Makanan yang bersifat vasodilator (anggur merah, natrium nitrat, dan natrium nitrit), vasokonstriktor (cokelat dan kafein), dan zatzat tambahan pada makanan seperti natrium nitrat, natrium nitrit, monosodium glutamat (MSG), dan aspartam memberikan kontribusi sebesar 26,9\% sebagai pencetus migrain. ${ }^{4}$

Kafein merupakan suatu zat psikoaktif. Mengonsumsi kafein mampu membuat orang terjaga dan meningkatkan konsentrasi dalam jangka pendek. Banyak orang yang sering mengonsumsi kafein secara rutin karena zat ini banyak terdapat di dalam kopi, teh, soda, dan coklat. Kandungan kafein dalam 3-4 cangkir kopi per hari ialah sekitar 300-400 mg. ${ }^{5}$ Indonesia merupakan penghasil kopi terbesar keempat di dunia. Hal ini mungkin berhubungan dengan angka konsumsi kopi nasional yang mencapai $>300.000$ ton tiap tahunnya sejak tahun $2018 .^{6}$

Kafein secara patobiologis dapat mencetuskan migrain karena efek vasokonstriktornya. Di sisi lain, kafein diketahui juga diketahui memiliki efek analgesik yang dapat dipakai pada manajemen nyeri kepala. ${ }^{7}$ Dalam perannya pada manajemen nyeri kepala (migrain), kafein secara luas digunakan sebagai ajuvan karena dapat meningkatkan efektivitas obat-obat yang digunakan untuk mengobati migrain. ${ }^{8}$

Individu yang sudah lama mengonsumsi kafein seperti orang yang gemar minum kopi atau orang yang setiap bekerja selalu mengonsumsi kafein (misalnya dalam bentuk kopi atau minuman berenergi) biasanya akan mengalami efek toleransi kafein sehingga harus mengonsumsi jumlah kafein yang lebih banyak dibanding sebelumnya untuk mencapai efek yang sama. Individu yang tidak mengonsumsi kafein dalam rentang waktu tertentu akan mengalami gejala-gejala seperti mengantuk dan lemas. Gejala-gejala ini disebut dengan gejala putus kafein (caffeine withdrawal symptoms). Timbulnya nyeri kepala termasuk timbulnya serangan migrain juga merupakan gejala putus kafein. Tingkat keparahannya berbeda-beda karena setiap orang memiliki besaran konsumsi kafein yang berbeda tiap harinya. Dosis harian $100 \mathrm{mg}$ (kurang lebih sama dengan secangkir kopi) sampai $300 \mathrm{mg}$ sudah mampu menyebabkan gejala putus kafein. Gejala tersebut biasanya muncul dalam 12-24 jam setelah terakhir kali mengonsumsi kafein dan umumnya berakhir dalam 2-9 hari. Puncak gejala umumnya terjadi pada dua hari pertama. ${ }^{9}$

Berbagai studi melaporkan adanya hubungan antara migrain dan kafein dengan hasil bervariasi. Berdasarkan hal ini maka penulis tertarik untuk menelusuri lebih dalam mengenai hubungan migrain dan konsumsi kafein melalui suatu literature review.

\section{METODE PENELITIAN}

Penelitian ini merupakan suatu literature review secara daring dengan menggunakan database dari Pubmed/Medline, Cochrane, Wiley Online Library, Science Direct, Google Scholar, dan Garuda. Kata kunci yang digunakan ialah "migraine" atau "migrain"/ "migren", dan "cephalgia" atau "sefalgia", "headache" atau "nyeri kepala", "caffeine" atau "kafein", "coffee" atau "kopi". Algoritma Boolean diterapkan untuk meningkatkan akurasi pencarian. Pencarian kata kunci dilakukan dengan mencari padanan kata dari komponen pertanyaan penelitian yang mungkin ditulis oleh penulis artikel. Selanjutnya pencarian kata kunci dipersempit dengan cara mengombinasikan kata kunci yang telah didapatkan sebelumnya dengan menggunakan kata penghubung "and".

Artikel yang diperoleh disesuaikan dengan kriteria kelayakan penelitian, yaitu artikel penelitian observasional atau uji 
klinis dalam Bahasa Indonesia atau Inggris yang terbit dalam lima tahun terakhir. Selain itu, naskah lengkap artikel penelitian harus dapat diakses secara lengkap. Alur yang digunakan untuk mencari dan menentukan artikel yang diteliti secara lebih lengkap dimodifikasi dari diagram Preferred Reporting Items for Systematic Reviews and Meta-analyses (PRISMA) tahun 2009 oleh Moher et al. ${ }^{10}$

\section{HASIL PENELITIAN}

Hasil penelitian mendapatkan 10 literatur yang memenuhi kriteria kelayakan penelitian; kesemuanya merupakan penelitian survei, yaitu: Penelitian Peris et al ${ }^{11}$ (2016), Booth et $\mathrm{al}^{12}$ (2018), Alstadhaug et al ${ }^{13}$ (2017), Siregar ${ }^{14}$ (2017), Tai et $\mathrm{al}^{15}$ (2017), AlFadeel et $\mathrm{al}^{16}$ (2017), Lee et $\mathrm{al}^{17}$ (2016), Beh et $\mathrm{al}^{18}$ (2019), Baratloo et al ${ }^{19}$ (2017). Dan Novianty ${ }^{20}$ (2017). Tabel 1 menunjukkan rangkuman kajian kesepuluh penelitian tersebut. Literatur yang memiliki sampel terbanyak ialah penelitian Booth et $\mathrm{al}^{12}$ dan yang paling sedikit ialah penelitian Alstadhaug et al. ${ }^{13}$

Dari 10 penelitian yang dikaji, didapatkan hubungan antara kafein dan migrain, Pada hampir semua penelitian terlihat bahwa kafein dapat menyebabkan migrain baik setelah kafein dikonsumsi (kelompok nonabsen) maupun saat kafein sedang tidak dikonsumsi (kelompok absen). Tabel 2 memperlihatkan bahwa sembilan dari 10 penelitian menunjukkan adanya hubungan antara kafein dan migrain. Pada kelompok nonabsen semua subjek dari penelitian Novianty ${ }^{20}$ mengalami migrain namun pada penelitian Beh et al, ${ }^{18}$ hanya $11,5 \%$ saja yang mengalami migrain.

Pada penelitian ini didapatkan hanya tiga literatur yang membahas kelompok absen. Sekitar 53\% dari total jumlah subjek penelitian Alstadhaug et al $^{13}$ mengalami migrain sementara hanya $33 \%$ dari total jumlah sampel penelitian Lee et $\mathrm{al}^{17}$ yang mengalami migrain pada kelompok absen. Terdapat dua literatur yang memiliki data kedua kelompok tersebut. Yang pertama ialah penelitian Alstadhaug et $\mathrm{al}^{13}$ yang semua sampelnya mengalami migrain dan dibagi atas dua kelompok, yaitu kelompok absen (53\%) dan kelompok nonabsen (47\%). Yang kedua ialah penelitian Lee et al ${ }^{17}$ yang semua sampelnya juga mengalami migrain dengan sekitar $66,7 \%$ dari total jumlah sampelnya ialah kelompok nonabsen.

Hal yang menarik ialah kafein selain menjadi penyebab juga dapat berperan sebagai obat migrain. Beberapa penelitian yang dikaji menunjukkan peranan tersebut. Sebagai contoh antara lain hasil penelitian Baratloo et $\mathrm{al}^{19}$ (Tabel 3) yang membandingkan penggunaan kafein sitrat intravena dan magnesium sulfat $\left(\mathrm{MgSO}_{4}\right)$ intravena pada pasien migrain. Kelompok yang menggunakan kafein sitrat mengalami penurunan skor VAS (Visual Analog Scale) yang bermakna dari 9,0 ke 5,0 pada satu jam pertama dan ke 3,0 setelah dua jam. Sementara, kelompok yang menggunakan $\mathrm{MgSO}_{4}$ intravena mengalami penurunan skor VAS yang lebih bermakna yaitu dari 8,0 ke 2,0 pada satu jam pertama dan ke 0,0 setelah dua jam. Selain itu, pada pasien yang sedang tidak mengonsumsi kafein nampaknya efikasi terapi abortif spesifik migrain lebih tinggi dibanding jika sudah mengonsumsi kafein.

Tabel 4 menyajikan hasil dari penelitian Lee et $\mathrm{al}^{17}$ yang membandingkan tingkat efikasi pengobatan migrain berdasarkan kelompok absen dan kelompok nonabsen. Pada penelitian ini obat yang dipakai ialah golongan triptan. Penggunaan obat antiemetik hanya diberikan bila subjek mengalami mual dan muntah. Antiinflamasi nonsteroid tidak diberikan. Seluruh subjek diinstruksikan untuk mengonsumsi obat sebelum nyeri kepala menjadi lebih parah serta mengisi kuesioner Migraine Assessment of Current Therapy (migraine-ACT). Hasil penelitian tersebut memperlihatkan kelompok absen memiliki tingkat efikasi pengobatan migrain yang lebih tinggi dibanding kelompok nonabsen. 
Tabel 1. Ringkasan kajian sepuluh penelitian yang dianalisis

\begin{tabular}{|c|c|c|c|c|c|c|c|}
\hline No & Peneliti & Lokasi & Tahun & $\begin{array}{l}\text { Perempuan } \\
\quad \mathrm{N}(\%)\end{array}$ & $\begin{array}{c}\text { Laki-laki } \\
\mathbf{N}(\%)\end{array}$ & Total & Ringkasan Penelitian \\
\hline 1 & Beh et al & $\begin{array}{l}\text { Dallas, } \\
\text { Amerika } \\
\text { Serikat }\end{array}$ & 2019 & $\begin{array}{c}105 \\
(80,2 \%)\end{array}$ & $\begin{array}{c}26 \\
(19,8 \%)\end{array}$ & 131 & $\begin{array}{l}\text { Dari } 131 \text { subjek dengan migrain } \\
\text { vestibular, } 11,5 \% \text { melaporkan bahwa } \\
\text { kafein menjadi faktor pencetus migrain. }\end{array}$ \\
\hline 2 & Booth et al & $\begin{array}{l}\text { Selandia } \\
\text { Baru }\end{array}$ & 2018 & $\begin{array}{c}944 \\
(64,6 \%)\end{array}$ & $\begin{array}{c}491 \\
(33,6 \%)\end{array}$ & 2379 & $\begin{array}{l}\text { Sekitar } 20 \% \text { dari total subjek memenuhi } \\
\text { kriteria CUD, 33,3\% kriteria withdrawal, } \\
\text { dan 11,3\% CUD \& withdrawal. Sebanyak } \\
99,1 \% \text { subjek mengonsumsi kafein. }\end{array}$ \\
\hline 3 & $\begin{array}{l}\text { Alstadhaug } \\
\text { et al }\end{array}$ & Norwegia & 2017 & $\begin{array}{c}15 \\
(88.3 \%)\end{array}$ & $\begin{array}{c}2 \\
(11,7 \%)\end{array}$ & 17 & $\begin{array}{l}\text { Ada perbedaan yang signifikan antara } \\
\text { perbandingan proporsi subjek yang } \\
\text { mengalami migrain saat withdrawal } \\
\text { (plasebo) dengan yang mengonsumsi } \\
\text { kafein. }\end{array}$ \\
\hline 4 & Peris et al & Austria & 2016 & $\begin{array}{c}278 \\
(85,3 \%)\end{array}$ & $\begin{array}{c}48 \\
(14,7 \%)\end{array}$ & 326 & $\begin{array}{l}\text { Sebanyak } 7,7 \% \text { sampel melaporkan } \\
\text { kafein merupakan pencetus migrain dan } \\
\text { semakin banyak faktor pencetus migrain } \\
\text { maka rata-rata serangan migrain per bulan } \\
\text { lebih tinggi. }\end{array}$ \\
\hline 5 & Siregar & $\begin{array}{l}\text { Sumatera } \\
\text { Utara, } \\
\text { Indonesia }\end{array}$ & 2017 & $\begin{array}{c}38 \\
(50,7 \%)\end{array}$ & $\begin{array}{c}37 \\
(49,3 \%)\end{array}$ & 75 & $\begin{array}{l}\text { Terdapat } 82,7 \% \text { subjek yang mengalami } \\
\text { migrain dan } 18 \text { subjek melaporkan bahwa } \\
\text { kafein merupakan penyebab migrain. }\end{array}$ \\
\hline 6 & Novianty & $\begin{array}{l}\text { Sumatera } \\
\text { Utara, } \\
\text { Indonesia }\end{array}$ & 2017 & $\begin{array}{c}25 \\
(73,5 \%)\end{array}$ & $\begin{array}{c}9 \\
(26,5 \%)\end{array}$ & 34 & $\begin{array}{l}\text { Terdapat hubungan yang bermakna antara } \\
\text { konsumsi kafein \& migrain. }\end{array}$ \\
\hline 7 & Tai et al & Malaysia & 2017 & $\begin{array}{c}521 \\
(76 \%)\end{array}$ & $\begin{array}{c}163 \\
(24 \%)\end{array}$ & 684 & $\begin{array}{l}\text { Terdapat } 255 \text { subjek yang melaporkan } \\
\text { diet sebagai pencetus migrain. Diet paling } \\
\text { umum yang dilaporkan adalah kopi ( } 136 \\
\text { subjek). }\end{array}$ \\
\hline 8 & $\begin{array}{l}\text { AlFadeel } \\
\text { et al }\end{array}$ & Arab Saudi & 2017 & $\begin{array}{c}219 \\
(58,5 \%)\end{array}$ & $\begin{array}{c}155 \\
(41,5 \%)\end{array}$ & 374 & $\begin{array}{l}\text { Sekitar } 90 \% \text { dari total subjek } \\
\text { mengonsumsi kafein (teh, kopi, dan } \\
\text { cokelat). Sebanyak } 42 \% \text { melaporkan } \\
\text { bahwa sefalgia muncul saat tidak } \\
\text { mengonsumi kafein. Jumlah perempuan } \\
\text { yang menderita sefalgia lebih banyak } \\
\text { daripada laki-laki. }\end{array}$ \\
\hline 9 & Lee et al & Korea & 2016 & $\begin{array}{c}84 \\
(77,8 \%)\end{array}$ & $\begin{array}{c}24 \\
(22,2 \%)\end{array}$ & 108 & $\begin{array}{l}\text { Terdapat } 36 \text { subjek yang menghentikan } \\
\text { konsumsi kafein dan sisanya tetap } \\
\text { melanjutkan konsumsi kafein. Kelompok } \\
\text { subjek yang tidak mengonsumsi kafein } \\
\text { memiliki tingkat efikasi pengobatan } \\
\text { migrain yang lebih baik. }\end{array}$ \\
\hline 10 & $\begin{array}{l}\text { Baratloo } \\
\text { et al }\end{array}$ & Iran & 2017 & $\begin{array}{c}46 \\
(64,3 \%)\end{array}$ & $\begin{array}{c}24 \\
(35,7 \%)\end{array}$ & 70 & $\begin{array}{l}\text { Subjek dibagi dua kelompok berdasarkan } \\
\text { pengobatan yang didapatkan (kafein sitrat } \\
\text { iv \& } \mathrm{MgSO}_{4} \text { iv). Pada kelompok kafein } \\
\text { sitrat iv skor VAS turun secara signifikan } \\
\text { dari } 9,0 \text { ke } 5,0 \text { pada } 1 \text { jam pertama dan ke } \\
3,0 \text { pada jam ke- } 2 \text { sementara pada } \\
\text { kelompok } \mathrm{MgSO}_{4} \text { iv skor VAS turun dari } \\
8,0 \text { ke } 2,0 \text { pada } 1 \text { jam pertama dan ke } 0,0 \\
\text { pada jam ke- } 2 \text {. }\end{array}$ \\
\hline
\end{tabular}


Tabel 2. Pengaruh kafein sebagai pencetus migrain

\begin{tabular}{clcc}
\hline No & \multicolumn{1}{c}{ Peneliti } & \multicolumn{2}{c}{ Pengaruh kafein } \\
& & $\begin{array}{c}\text { Pencetus migrain } \\
\text { (Kelompok nonabsen) }\end{array}$ & $\begin{array}{c}\text { Pencetus migrain } \\
\text { (Kelompok absen) }\end{array}$ \\
\hline 1 & Beh et al & $15(11,5 \%)$ & \\
2 & Booth et al & $625(43,5 \%)$ & $9(53 \%)$ \\
3 & Alstadhaug et al & $8(47 \%)$ & \\
4 & Peris et al & $51(15,4 \%)$ & \\
5 & Siregar & $18(24 \%)$ & $158(42 \%)$ \\
6 & Novianty & $34(100 \%)$ & $36(33,3 \%)$ \\
7 & Tai et al & $136(19,9 \%)$ & \\
8 & AlFadeel et al & & \\
9 & Lee et al & $72(66,7 \%)$ & \\
10 & Baratloo et al & & \\
\hline
\end{tabular}

Tabel 3. Perbandingan penyuntikan intravena kafein sitrat dan magnesium sulfat pada pasien migrain

\begin{tabular}{clcc}
\hline No & \multicolumn{1}{c}{ Variabel } & Kafein sitrat & Magnesium sulfat \\
\hline 1 & Usia (tahun) & $30,2 \pm 1,5$ & $36 \pm 2,1$ \\
2 & Jenis kelamin (P/L) & $29 / 6$ & $19 / 16$ \\
3 & Skor skala nyeri visual & $9 \pm 3$ & $8 \pm 2$ \\
\hline
\end{tabular}

Tabel 4. Perbandingan tingkat efikasi pengobatan migrain

\begin{tabular}{lcc}
\hline & \multicolumn{2}{c}{ Kelompok subjek } \\
& $\begin{array}{c}\text { Kelompok } \\
\text { absen }\end{array}$ & $\begin{array}{c}\text { Kelompok } \\
\text { nonabsen }\end{array}$ \\
\hline Tingkat efikasi tinggi & $26(72,2 \%)$ & $29(40,3 \%)$ \\
\hline
\end{tabular}

\section{BAHASAN}

Kafein dapat menjadi salah satu faktor pencetus migrain baik saat kafein sudah dikonsumsi maupun saat kafein sedang tidak dikonsumsi. Penelitian oleh Beh et al ${ }^{18}$ mendapatkan bahwa sebanyak 11,5\% dari 131 subjek yang diteliti mengatakan bahwa kafein merupakan pencetus migrain paling umum. Sejalan dengan penelitian Peris et $\mathrm{al}^{11}$ dan Tai et $\mathrm{al}^{15}$ yang mendapatkan masing-masing sebanyak $7,7 \%$ dan $24 \%$ dari subjek yang diteliti melaporkan bahwa kafein merupakan pencetus migrain. Hal tersebut juga didukung oleh penelitian Booth et al ${ }^{12}$ yang menyatakan bahwa pada individu yang mengonsumsi kafein dalam dosis sedang, berpeluang untuk memenuhi kriteria caffeine use disorder (CUD) menjadi lebih besar 2,79 kali dan peluang untuk mengalami gejala putus zat naik sebesar 2,21 kali dibanding yang mengonsumsi kafein dalam dosis rendah.
Hal ini terjadi berdasarkan cara kerja kafein di otak yang menjadi antagonis reseptor adenosin, yaitu saat kafein berikatan dengan reseptor adenosin (tergantung lokasi kafein dan adenosin berikatan serta dosis kafein tersebut) umumnya akan terjadi vasokonstriksi. Saat vasokonstriksi otak merasa sedang kekurangan oksigen sehingga akan melakukan vasodilatasi sebagai bentuk kompensasi. Bila vasodilatasi terlalu kuat maka akan terjadi kebocoran plasma ke perivaskular yang menyebabkan keluarnya neuropeptida seperti calcitonin gene-related peptide (CGRP) dan memengaruhi sistem trigeminovaskular yang pada akhirnya akan merangsang reseptor dan jaras nosiseptif sehingga muncul rasa nyeri.

Hubungan antara kafein dengan migrain lebih erat dibandingkan dengan nyeri kepala lainnya seperti nyeri kepala tipe tegang. Hal ini terlihat pada penelitian Tai et $\mathrm{al}^{15}$ yang melibatkan 684 subjek. Terlihat bahwa kopi 
$(p=0,00)$ dan coklat $(p=0,00)$ secara bermakna lebih umum dikonsumsi oleh subjek yang menderita migrain dibanding yang menderita nyeri kepala tipe tegang.

Peran kafein sebagai vasokonstriktor, walaupun nantinya akan terjadi vasodilatasi pada saat nyeri kepala sebenarnya hanya menjadi dasar dari mekanisme terjadinya nyeri kepala itu sendiri. Aura pada migrain dapat terjadi akibat vasokonstriksi yang dicetuskan oleh kafein. Oleh karena itu aura muncul terlebih dahulu sebelum fase nyeri kepala. Jadi setelah vasokonstriksi berubah menjadi vasodilatasi barulah muncul respons nyeri pada migrain. Aura yang ditimbulkan saat terjadi vasokonstriksi juga makin memperkuat hasil penelitian bahwa kafein lebih erat hubungannya dengan migrain dibanding nyeri kepala tipe tegang. ${ }^{7,8}$

Gejala putus kafein atau caffeine withdrawal symptoms umum terjadi pada individu yang sudah mengalami adaptasi toleransi karena mengonsumsi kafein secara kronis sehingga ketidakhadiran kafein dalam tubuh dapat memunculkan gejala seperti migrain. ${ }^{8,9}$ Penelitian Alstadhaug et $\mathrm{al}^{13}$ yang meneliti 17 subjek yang sudah mengalami migrain dan mengonsumsi kafein $\geq 300 \mathrm{mg}$ sampai $\leq 800 \mathrm{mg}$ setiap hari selama minimal satu bulan, menemukan bahwa terdapat subjek yang meneruskan konsumsi kafeinnya dan ada yang menghentikan. Terdapat perbedaan bermakna antara perbandingan proporsi subjek yang mengalami migrain saat plasebo dan subjek yang mengonsumsi kafein. Sejalan dengan hasil penelitian Alstadhaug et al, ${ }^{13}$ penelitian AlFadeel et al $^{16}$ juga menunjukkan hasil yang sama, yaitu terdapat keluhan seperti nyeri kepala dan lelah bila kafein sedang tidak dikonsumsi. Perasaan seperti nyeri kepala diderita oleh hampir separuh $(42 \%)$ dari jumlah subjeknya saat mereka sedang tidak mengonsumsi kafein.

Saat kafein dikonsumsi rutin maka kafein akan terus berikatan dengan reseptor adenosin yang mengakibatkan adenosin tidak dapat berikatan dengan reseptornya. Bentuk kompensasi yang dilakukan terhadap hal ini ialah dengan memperbanyak jumlah reseptor tersebut agar adenosin dapat berikatan kembali dengan reseptornya sehingga dibutuhkan lebih banyak kafein untuk mencetuskan efek yang sama dibandingkan saat pertama kali dikonsumsi; hal ini dinamakan toleransi adaptasi. Semakin sering individu tersebut mengonsumsi kafein maka reseptor adenosin akan semakin banyak. Bila individu tersebut menghentikan konsumsi kafeinnya maka adenosin yang berikatan akan jauh lebih banyak sehingga dapat terjadi vasodilatasi berlebihan yang akan mencetuskan respons nyeri. ${ }^{8}$

Selain menjadi salah satu faktor pencetus migrain, kafein juga dapat meredakan nyeri kepala akibat migrain karena efek dari kafein itu sendiri yang menyebabkan vasokonstriksi pembuluh darah otak. Melalui penelitian Baratloo (Tabel 4), dapat dilihat bahwa walaupun kelompok yang mendapat pengobatan dengan kafein sitrat intravena tidak lebih efektif dibandingkan dengan kelompok yang mendapat pengobatan dengan $\mathrm{MgSO}_{4}$ intravena dalam menurunkan nyeri kepala akibat migrain, namun pada penelitian ini kafein terbukti dapat menurunkan nyeri kepala akibat migrain dengan adanya penurunan skor VAS pada kelompok yang mendapat pengobatan kafein sitrat intravena.

\section{SIMPULAN}

Terdapat hubungan erat antara migrain dan kafein. Migrain cenderung lebih sering dicetuskan oleh kafein dibandingkan diringankan oleh kafein.

\section{Konflik Kepentingan}

Penulis menyatakan tidak terdapat konflik kepentingan dalam studi ini.

\section{DAFTAR PUSTAKA}

1. Haryani S. Penatalaksanaan nyeri kepala pada layanan primer. Callosum Neurol. 2018; 1(3):80-8. Available from: https://doi. org/10.29342/cnj.v1i3.16

2. Ahmed F. Headache disorders: differentiating and managing the common subtypes. $\mathrm{Br}$ J Pain. 2012;6(3):124-32. Available from: https://www.ncbi.nlm.nih.gov/ pmc/articles/PMC4590146/

3. Mueller LL. Diagnosing and managing migraine headache. J Am Osteopath 
Assoc. 2007;107(10Supp16):10-6. Available from: https://pubmed.ncbi.nlm. nih.gov/17986672/

4. Dewanto G, Wilfrid DM. Migrain. In: Panduan Praktis Diagnosis \& Tata Laksana Penyakit Saraf. Jakarta: EGC, 2009. Available from: https://opac.perpusnas. go.id/DetailOpac.aspx?id=472423

5. Nieber K. The impact of coffee on health author pharmacokinetics and mode of action bioactive components in coffee. Planta Med. 2017;83(1):1256-63. Available from: https://www.thieme-connect.de/ products/ejournals/html/10.1055/s0043-115007

6. Kementerian Pertanian. Outlook Kopi [Internet]. Pusat Data dan Sistem Informasi Pertanian Sekretariat Jenderal - Kementerian Pertanian 2019. Jakarta; 2017. 106 p. Available from:http://epublikasi. setjen.pertanian.go.id/arsip-outlook/75outlook-perkebunan/547-outlook-kopi2017

7. Fernández-Dueñas V, Sánchez S, Planas E, Poveda R. Adjuvant effect of caffeine on acetylsalicylic acid anti-nociception: prostaglandin E2 synthesis determination in Carrageenan-induced peripheral inflammation in rat. Eur J Pain. 2008; 12:157-63. Available from: https:// onlinelibrary.wiley.com/doi/abs/10.101 6/j.ejpain.2007.03.485

8. Nowaczewska M, Wiciński M, Kaźmierczak $\mathrm{W}$. The ambiguous role of caffeine in migraine headache: from trigger to treatment. Nutrients. 2020;12(8):1-16. Available from:https://www.ncbi.nlm. nih.gov/pmc/articles/PMC7468766/

9. Prasetio A. Gangguan psikiatri terkait kafein. Cermin Dunia Kedokt [Internet]. 2020;47(5):378-82. Available from: http://103.13.36.125/index.php/CDK/ar ticle/download/603/379

10. Moher D, Liberati A, Tetzlaff J, Altman DG, Altman D, Antes G, et al. Preferred reporting items for systematic reviews and meta-analyses: The PRISMA statement. PLoS Med. 2009;6(7). Available from:https://doi.org/10.1371/journal. pmed. 1000097

11. Peris F, Donoghue S, Torres F, Mian A, Wöber C. Towards improved migraine management: determining potential trigger factors in individual patients. Cephalgia. 2017;37(5):452-63. Available from::
https://doi.org/10.1177\%2F033310241 6649761

12. Booth N, Saxton J, Rodda SN. Estimates of caffeine use disorder, caffeine withdrawal, harm and help-seeking in New Zealand: a cross-sectional survey. Addict Behav. 2020;109(Nov 2019). Available from:https://doi.org/10.1016/ j.addbeh.2020.106470

13. Alstadhaug KB, Ofte HK, Müller KI, Andreou AP. Sudden caffeine withdrawal triggers migraine - a randomized controlled trial. Front Neurol. 2020;11(Sept):1-7. Available from:https://doi.org/10.3389/ fneur.2020.01002

14. Siregar A. Prevalensi migrain dan faktor yang mempengaruhinya pada pegawai FK USU Tahun 2017 [Internet]. Universitas Sumatera Utara; 2017. Available from:http://repositori.usu.ac.id/handle/1 23456789/4528

15. Tai MLS, Yap JF, Goh CB. Dietary trigger factors of migraine and tension-type headache in a South East Asian Country. J Pain Res. 2018;11:1255-61. Available from:https://www.ncbi.nlm.nih.gov/pm c/articles/PMC6029602/

16. AlFadeel M, Shaban A, Neyaz B, AlAli H, Neyaz S, Alkhrissi N, et al. Consumption of caffeine and its perceived effect among staff and students of medicine at AlMaarefa University, Saudi Arabia. Int J Med Dev Ctries. 2020;4(June):1112-5. Available from: https://doi.org/10. 24911/IJMDC.51-1579177663

17. Lee MJ, Choi HA, Choi H, Chung CS. Caffeine discontinuation improves acute migraine treatment: a prospective clinicbased study. J Headache Pain. 2016; 17(1):0-5. Available from:http://dx.doi. org/10.1186/s10194-016-0662-5

18. Beh SC, Masrour S, Smith S V., Friedman DI. The spectrum of vestibular migraine: clinical features, triggers, and examination findings. Headache. 2019;59(5): 727-40. Available from:https://doi.org/ 10.1111/head.13484

19. Baratloo A, Mirbaha S, Kasmaei HD, Payandemehr P, Elmaraezy A, Negida A. intravenous caffeine citrate vs. magnesium sulfate for reducing pain in patients with acute migraine headache; a prospective quasi-experimental study. Korean J Pain. 2017;30(3):176-82. Available from:http://www.epain.org 
/journal/view.html?volume=30\&numbe $\mathrm{r}=3$ \&spage $=176$.

20. Novianty. Hubungan konsumsi kafein dengan intensitas nyeri kepala pada penderita migren [Internet]. Universitas Sumatera Utara; 2017. Available from:http:// repositori.usu.ac.id/handle/123456789/ 20004. 